\title{
INCIDENCE OF RHINOSPORODIOSIS IN CHILDREN- A RETROSPECTIVE STUDY IN TERTIARY CARE HOSPITAL.
}

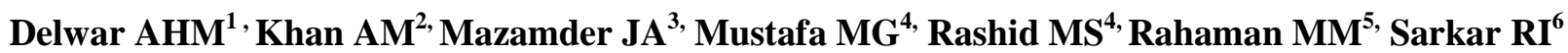

DOI: $10.31364 /$ SCIRJ/v8.i1.2020.P0120738

http://dx.doi.org/10.31364/SCIRJ/v8.i1.2020.P0120738

\begin{abstract}
:
Background:

Rhinosporodiosis is a sporadic chronic granulomataous inflammation of the mucocutanous tissue caused by a protozoon, rhinosporodium seeberi or kinealyi. The disease mostly affects nose and nasopharynx. Other sites are lips, palate, conjunctiva, larynx, trachea, vulva and vagina. It occurs mostly in our subcontinent specially in India, Srilanka, Pakistan and Bangladesh and people in low socioeconomic condition where human beings and animals both are using same ponds for their bathing and washing.
\end{abstract}

\section{Methods:}

A retrospective study of 30 children with rhinosporodiosis out of total patients attended in outpatient department of otolaryngology and Head-Neck surgery and total 64 rhinosporodiosis operative patient from 01-07-2016 to 31-06-2019 in cumilla medical college hospital, Bangladesh.

\section{Result:}

During this three years total outpatient is 116128, in which children with rhinosporodiosis is 30 ( $0.02 \%)$, Out of total 30525 inpatient department is $0.09 \%$, out of total 2738 operative patient is ( 1.09\%) and out of total 64 rhinosporodiosis patient is $46.87 \%$.

\section{Conclusion:}

Rhinosporodiosis is an enigmatic chronic granulomatous disease which is seen in all age group including children in those who are using surface water sources for daily requirements. It is important for children that they are equal risk like adult.

\section{Introduction:}

Rhinosporodiosis is a chronic granulomatous disease condition caused by an aquatic protozoon previously considered to be a fungus is still debating subject in medical science. ${ }^{1}$ The etiologic agent of rhinosporodiosis, Rhinosporodium Seeberi is closely related to several protoctistiae fish pathogens. ${ }^{2}$ The infection affects nasal mucous membrane and ocular conjunctiva of human and animals, slowly growing mass that degenerate into polyps. Now it isn't consider as a fungal disease. A granuloma is an organized collection of macrophage known as epitheloid cells which fuse to form multineucleated giant cells. The histological configuration is encountered in a number of infective, inflammatory neoplastic condition of the nose and sinuses. It is sporadic, but most of the $90 \%$ cases come from India, Srilanka, Pakistan and Bangladesh. Some cases have been reported from Africa, South America, North America, Europe and Canada. No cases reported from Australia. 'Disease is also seen to involve animals such as cows, bulls, horses and dogs where the man and animals share the same infected ponds. ${ }^{3}$ A bleeding raspberry like polypus of the nasal mucosa is the presenting sign. The disease mostly affects nose and nasopharynx. Other sites are lips, palate, conjunctiva, epiglottis, larynx, trachea, bronchi, skin, vulva and vagina may also be affected. The disease is acquired through contaminated water of ponds also frequented by animals. ${ }^{4}$ On examination anterior rhinoscopy shows 1. A leafy polypoidal mass. 2. Pink or purple in colour. 3. Attached to lateral wall or nasal septum. 4. The mass is bleeding on touch. 5. Its surface is studded with white dots representing the sporangia of rhinosporodium seeberi. Sometime it extends to nasopharynx and hanging behind the uvula. Diagnosis is confirmed by excision biopsy and histopathology. ${ }^{5}$ 


\section{Methods:}

It is a retrospective study of 30 children suffering from rhinosporodiosis who were attended in the outpatient department of the Otolaryngology and Head-Neck Surgery, cumilla medical college hospital, Bangladesh from 01-07-2016 to 31-06-2019. The children age is upto 18 years according to WHO and UNICEF. We collect the total number of patient from outpatient register who were attended in the outdoor during this time. The total number of patient is 116128 during that time. 30525 patients had got admitted in the inpatient department for both medical and surgical treatment. During this time 2738 routine operation has been performed. Out of 2738 , rhinosporodiosis patient is 64 in which children is 30. All the patient of Rhinosporodiosis were treated surgically which is practiced normally (Excision and wide base cauterization). These data were calculated and compared to other literatures.

Table-1

$\mathrm{N}-116128$

Incidence of rhinosporodiosis in outpatient department:

\begin{tabular}{|c|c|c|c|}
\hline Serial No. & Study Group & Result & Percentage \\
\hline 1 & Total Outdoor Patient & 116128 & $0.02 \%$ \\
\hline 2 & Children Patient & 30 & 0 \\
\hline
\end{tabular}

Table-2

N-30525

Incidence of Rhinosporodiosis in inpatient department:

\begin{tabular}{|c|c|c|c|}
\hline Serial No. & Study Group & Result & Percentage \\
\hline 1 & Total Indoor Patient & 30225 & \\
\hline 2 & Children Patient & 30 & $0.09 \%$ \\
\hline
\end{tabular}

Table-3

$\mathrm{N}-2738$

Incidence of rhinosporodiosis in routine operative patient:

\begin{tabular}{|c|c|c|c|}
\hline Serial No. & Study Group & Result & Percentage \\
\hline 1 & Total Operation Performed & 2738 & \\
\hline 2 & Children Patient & 30 & $1.09 \%$ \\
\hline
\end{tabular}

Table-4

$\mathrm{N}-64$

Incidence of Children in total rhinosporodiosis patient:

\begin{tabular}{|c|c|c|c|}
\hline Serial No. & Study Group & Result & Percentage \\
\hline 1 & Total Rhinosporodiosis Operation & 64 & \\
\hline 2 & Children Patient & 30 & $46.87 \%$ \\
\hline
\end{tabular}


Chart-1

N-30

Gender Epidemiology: Male-50\%, Female-50\%

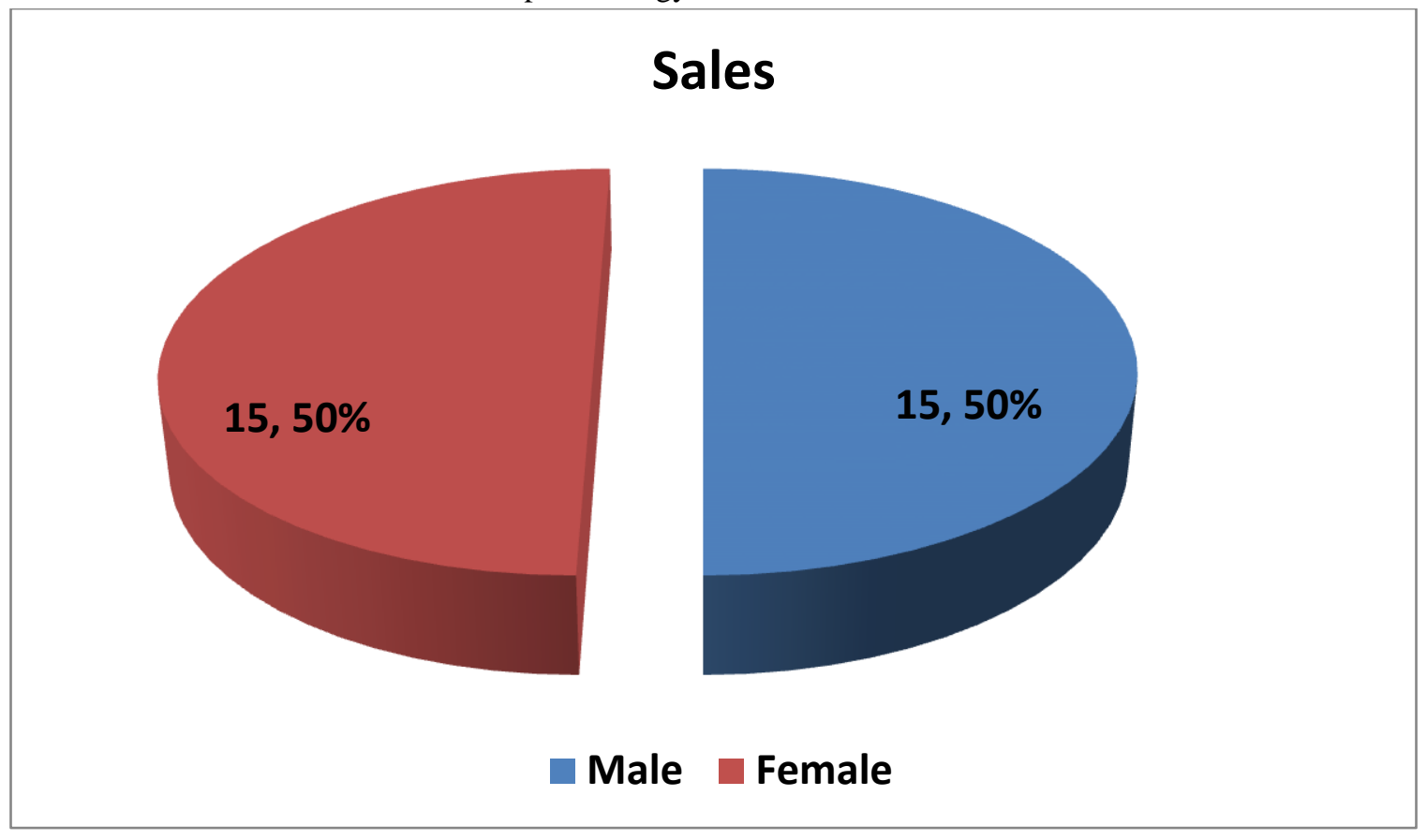

\section{Result:}

Incidence of rhinosporodiosis in children out of 116128 patients who were attended in the outpatient department of Otolaryngology and Head-Neck Surgery is $0.02 \%$ (Table-1). 30525 patients were got admitted in the indoor department from which children is $0.09 \%$ (Table-2). During that time 2738 routine surgery were performed where 64 patients were diagnosed as rhinosporodiosis. Incidence of rhinosporodiosis in children out of 2738 is $1.09 \%$ (Table-3) and out of 64 is $46.87 \%$ (Table-4) which is near to adult. Gender epidemiology in 30 children patient is equal $50 \%$ between both male and female (Chart-1).

\section{Discussion:}

Bangladesh is a country of ponds, Tanks and Rivers. According to Bangladesh Water Development Board about 230 rivers currently flow in Bangladesh during summer and winter. The delta plan of the Ganga(Padda), Brahmaputra(Jomuna), Meghna river and their tributaries occupy $79 \%$ of the country. A large number of people depend on them for living and transportation. It is considered that ground water is natural habitant of Rhinosporodium Seeberi. The adult and children who are living by the side of these rivers and tributaries, they are using these water source for bathing and washing. Every village and home has their own ponds which are also use for bathing themselves and washing their daily requirements. The cattles are also washing in some ponds and rivers. So incidence of rhinosporodiosis is higher among them. ${ }^{6}$ The study revealed the nature of the disease and the history revealed frequent ponds bath by the children because the parents aren't aware of all their activities. ${ }^{7}$ The patient mode of infection is probably responsible for increase number of case detection in our studies because our greater cumilla is situated by the side of three big river Gomti, Podda and Titas and their tributaries. A large number of people and children are from low socioeconomic condition. They are using river and ponds water and prone to mucosal infection by sands and dust water which is similar to Sinha et al series. ${ }^{8}$ Our experience is same and common that they are bathing, washing and practicing swimming in the ponds, lakes and rivers where the cattle like cows and horses are also washing. It is similar to Vukovic et al series where the people spent their holidays in the side of silver lake in Europe and they are enjoying by bathing and swimming in the lake. ${ }^{9}$ In gender epidemiology male and female number is same in our study which is near to another study in India where male and female ratio is $57 \%$ and $43 \%$ accordingly. ${ }^{10}$ Total excision and wide base cauterization is the principle of treatment. Now a days endoscopic technique is used for precise excision. ${ }^{11}$ Recurrence of rhinosporodiosis after surgical excision isn't uncommon. It is due to spillage of endospores in the surrounding mucosa during 
removal, even may occur by senior and expert surgeon. ${ }^{12}$ Not many drugs are effective against the rhinosporodiosis. Antileprotic drugs Dapsone has been tried with some success to prevent recurrence. It can also be used as an adjunct to surgery. ${ }^{13}$

\section{Conclusion:}

Rhinosporodiosis is a chronic granulamatous disease which is seen in all age group including children who are using surface water source for their daily requirements. Hopefully knowledge will probably lead to development of more efficient therapeutic modalities and sound protocol for the prevention of disease. It is more important for children that they are equally risk like adult. The children doesn't notice the symtom early. So in case of children careful follow up is essential for early diagnosis of reccurence.

\section{Reference:}

1. Herr RA, Ajello L, Taylor JW, Arseculeratne SN, Mendoza L(1999a). Phylogenetic analysis of Rhinosporodium Seeberi 18S small- subunit ribosomal DNA groups this pathogen among members of the Protoctistan Mesomycetozoa Clade. J. Clin. Microbiol. 37(9):2750-2754.

2. Ahluwalia KB, Maheshwar N, Deka RC. Rhinosporodiosis: a study that resolves etiologic controverseries. American J. Rhinol. 1997;11(6):479-83.

3. Morelli L, Polce M, Piscioli F, Del nonno F, Covello R, Brenna A, Licci S.(2006). Human Nasal Rhinosporodiosis an Italian Case Report. Diagn. Pathol. 1:25, http//dx.doi.org/10.1186/1746-1596-1-25.

4. Pal M(1995). Nasal rhinosporodiosis in Guzrat(India) Rev. Iberia Americana de Micologia. 12:61-62.

5. Levy MG, Meutem DJ, Breitschwerdt EB (1986). Cultivation of Rhinosporodium Seeberi in Vitro; interaction with epithelial cell. 234:474-476. http;//dx.doi.org/10.1126/science .3764422.

6. Karunaratne WAE. The Pathology of Rhinosporodiosis. J Path and Bact. 1936;42:193-202.

7. Ahmed NA, Mohammed S, Raj G.(2013) Rhinosporodiosis: An epidemiological study. J.Evo.Med. Dental. Sci.38:72277233.

8. Sinha A,Phukan JP, Bandyopadhyay G, Sengupta S, Bose K, Mondal RK, Choudhuri MK. Clinicopathological study of rhinospodiosis with special reference to cytodiagnosis. J Cytol $2012 ; 29: 246-9$.

9. Vukovic Z, Bobic-Radovanovic A, Latkovic Z, Radovanovic Z (1995). An epidemiological investigation of the first outbreak of rhinosporodiosis in Europe. J. Trop. Med. Hyg.98: 333-337.

10. Arseculeratne SN. Recent advances in rhinosporodiosis and Rhinosporodium Seeberi. Indian J Med. Microbiol 2002;20:119-31.

11. Sonkhya N, Singhal P, Mishra P. Naso-oropharyngeal rhinosporodiosis-Endoscopic removal. Indian J otolaryngol Head Neck Surg. 2005:57(4); 354-6.

12. Ahluwalia KB. New interpretation in rhinosporodiosis, enigmatic disease of the last nine decades. J Submicros Cytol Pathol 1992;24:109-14.

13. Job A, Venkateswaran S, Mathan M, Krishnaswami H, Raman R. Medical therapy of rhinosporodiosis with Dapsone. J Laryngol Otol 1993;107:809-12.

\section{Authors:}

Dr A H M Delwar, Associate Professor of Otolaryngology, Cumilla Medical College.

Dr Arif Murshed Khan, Assistant Professor of Otolaryngology, Cumilla Medical College.

Dr Jahangir Alam Mazumder, Associate Professor of Otolaryngology, Cumilla Medical College.

Dr Shazibor Rashid, Associate Professor of Otolaryngology, Cumilla Medical College.

Dr Golam Mustafa, Associate Professor of Otolaryngology, Cumilla Medical College.

Dr Md Mostafizur Rahaman, Assistant Professor of Otolaryngology, Cumilla Medical College.

Dr Rafiqul Islam Sarkar, Associate Professor of Otolaryngology and Vice Principal, Cumilla Medical College.

\section{Address in Correspondence:}

Dr A H M Delwar, Associate Professor of Otolaryngology, Cumilla Medical College.

Email-mamun.delwar196@gmail.com

Mobile-+8801711246978. 